\title{
WATER QUALITY INDICES - METHODS FOR EVALUATING THE QUALITY OF DRINKING WATER
}

$\underline{\text { Iuliana Paun }}^{1}$, Liliana Valeria Cruceru${ }^{1}$, Florentina Laura Chiriac ${ }^{1}$, Marcela Niculescu ${ }^{1}$, Gabriela Geanina Vasile ${ }^{1}$, Nicoleta Mirela Marin ${ }^{1}$

${ }^{1}$ National Research and Development Institute for Industrial Ecology-ECOIND, 71-73 Drumul Podu Dambovitei, sector 6, Bucharest, 060652, Romania

\begin{abstract}
Water quality is assessed through the biological, physical and chemical parameters. The limits of these parameters that are harmful to human health have been established at national or international level (WHO, EPA, MECC) by various laws, regulations, normative. An efficient and simplified to express the quality of water for consumption is given by the water quality index. It reflects the quality of water in a single value by comparing data obtained from the investigation of a number of physico-chemical and bacteriological parameters with existing limits. This number is placed on a relative scale to justify the quality of water in categories ranging from very poor to excellent. In this study are discussed various water quality indices used to assess the quality of drinking water (surface water). National and international agencies involved in assessing water quality and pollution control defines different quality criteria used for drinking water which is why there are many water quality specific indices for each region or area. In this context, it will present a comparative study of the most important quality indices used to assess water quality worldwide.
\end{abstract}

Keywords: drinking water, surface water, water quality, water quality index

\section{Introduction}

The most important drinking water resurces in the world are the surface water and groundwater. Traditionally, drinking water quality status is professional communicated by comparing the individual parameters (physical, chemical and biological parameters) with guideline values. The limits of those parameters that are harmful to human health have been established at national or international level (WHO, EPA, MECC) by various laws, regulations, normatives.

The water quality index aims at assessing the quality of water through a single numerical value, calculated on the basis of one system which convert all the individual parameters and their concentrations, present in a sample into a single value. This is an effective method that allows to compare the quality of various water samples based on a single numerical value and not only the parameters values of each sample.

Any result of water quality measurements can serve as indicator of water quality.

During the years have been formulated several water quality indices by some national or international organization, which were applied for evaluation of water quality in different particular cases. At global level is not a single index that can describe overall water quality for any water body. However, such a global index of water quality is needed to assess changes in water quality over time and space and also to evaluate successes and failures of international treaties designed to protect aquatic resources. A number of countries have begun the process of developing composite indices of water quality to describe the state of their domestic waters, including the United States of America (Cude 2001), Taiwan (Liou et al. 2004), Argentina (Pesce and Wunderlin 
2000), Australia (ICS 2005), Canada (Khan et al.2003; Lumb et al. 2006; CMME 2001) and New Zealand (Smith 1989,1990; Nagels at al. 2001) [1-10].

The present study reports the most important water quality indices used in water quality assessment, their mathematical structure as well as their merits and demerits, which are used worldwide.

\section{Water Quality Index}

Historically, different organizations of several nationalities involved in water resources control have used the water quality indices for water quality assessment. This has been more evident in the last decade of the 20th Century.

Initially, water quality index (WQI) was developed by Horton (1965) [11] in United States by selecting 10 most commonly used water quality variables like dissolved oxygen, $\mathrm{pH}$, coliforms, specific conductance, alkalinity and chloride etc. and has been widely applied and accepted in European, African and Asian countries.

The assigned weight reflected significance of a parameter for a particular use and has considerable impact on the index. Furthermore, a new WQI similar to Horton's index has also been developed by the group of Brown in 1970 [12], which was based on weights to individual parameter.

Many modifications have been considered for WQI concept through various scientists and experts.

A general water quality index (WQI) is based on the most common factors, which are described in the following four steps:

1. Selection the water quality parameters to be included.

2. Transformation of the raw parameter data onto a common scale.

3. Decision on the relative weights to be allocated to the index components.

4. Specification of the aggregation function, including, where possible, controlling for the sampling design of the water quality monitoring data.

However, a huge number of water quality indices: Weight Arithmetic Water Quality Index (WAWQI), National Sanitation Foundation Water Quality Index (NSFWQI), Canadian Council of Ministers of the Environment Water Quality Index (CCMEWQI), Oregon Water Quality Index (OWQI) etc. have been formulated by several national and international organizations.

These WQI have been applied for evaluation of water quality in a particular area. Moreover, these indices are often based on the varying number and types of water quality parameters as compared with respective standards of a particular region.

Water quality indices are used to demonstrate annual cycles, spatial and temporal variations in water quality and trends in water quality even at low concentrations in an efficient and timely manner.

On the basis of reviewed literature, available indices have many variations and limitations based on number of water quality variables used and not accepted worldwide.

The National Sanitation Foundation Water Quality Index (NSFWQI) is the most respected and utilized water quality index in the U.S. However, this index has been criticized for not adequately representing water quality in all areas of the U.S. The "one size fits all" structure of the index causes some regional water quality concerns to be overlooked in the overall index value. The proposed method for comparing the water quality of various water sources is based upon nine water quality parameters such as temperature, $\mathrm{pH}$, turbidity, fecal coliform, dissolved oxygen, biochemical oxygen demand, total phosphates, nitrates and total solids. [12-14]

The water quality data are recorded and transferred to a weighting curve chart, where a numerical value of Qi is obtained. The mathematical expression for NSF WQI is given by 
Where,

$$
\mathrm{WQI}=\sum_{i=1}^{n} Q i W i
$$

QI = sub-index for ith water quality parameter;

$W i=$ weight associated with ith water quality parameter;

$n=$ number of water quality parameters.

For this NSFWQI method, the ratings of water quality have been defined by using following Table 1.

Canadian Council of Ministers of the Environment Water Quality Index (CCME WQI) provides an overall measure of the suitability of water bodies to support aquatic life at selected monitoring sites in Canada. The indicator is based on applications of the Water Quality Index (WQI). Given that aquatic life can be influenced by the presence of hundreds of both natural and anthropogenic substances in water, the WQI provides a useful tool that allows experts to translate vast amounts of water quality monitoring information into a simple overall rating. $[7,8]$

The CCME WQI relates water quality data to the various beneficial uses of water by using relevant water quality guidelines as benchmarks. Each index is calculated for an individual monitoring site during a chosen reference period. Water samples collected over this period of time are analyzed for a suite of water quality parameters. The measured values of each parameter are compared to the appropriate water quality guideline. These are called tests. The percentage of parameters and tests that fail to meet the guidelines, as well as the deviation from the guideline for tests that do not meet guidelines, are captured in three factors used in the calculation of the index. These factors are scope $\left(F_{1}\right)$, frequency $\left(F_{2}\right)$, and amplitude $\left(F_{3}\right)$. The index yields a number between 0 and 100. A higher number indicates better water quality.

$$
\mathrm{CCME} W Q \mathrm{~W}=100-\left(\frac{\sqrt{\mathrm{F}_{1}^{2}+\mathrm{F}_{2}^{2}+\mathrm{F}_{3}^{2}}}{1.732}\right)
$$

Scope $\left(F_{1}\right)$ : The scope factor represents the percentage of the total number of parameters that fail to meet the water quality guidelines at any time during the reference period.

$$
F_{1}=\left(\frac{\text { number of failed parameters }}{\text { total number of parameters }}\right) \times 100
$$

Frequency $\left(F_{2}\right)$ : The frequency factor represents the percentage of individual tests that fail to meet the water quality guidelines.

$$
\mathrm{F}_{2}=\left(\frac{\text { number of failed tests }}{\text { total number of tests }}\right) \times 100
$$

A failed test occurs when an individual parameter value within a sample exceeds the guideline. The total number of failed tests represents the total number of failed parameter values in every sample during the reference period. The total number of tests for an individual site is calculated by multiplying the average number of parameters per sample by the total number of samples during the reference period.

Amplitude $\left(F_{3}\right)$ : The amplitude factor represents the average deviation of failed test values from their respective guidelines. The relative deviation of a failed test from the guideline is termed an excursion and is calculated as follows:

When the test value must not exceed the guideline:

$$
\text { excursion }_{i}=\left(\frac{\text { failed test value }_{i}}{\text { guideline value }_{\mathrm{i}}}\right)-1
$$

When the test value must not fall below the guideline: 


$$
\text { excursion }_{\mathrm{i}}=\left(\frac{\text { guideline value }_{\mathrm{i}}}{\text { failed test value }_{\mathrm{i}}}\right)-1
$$

The collective amount by which individual tests are out of compliance is calculated as follows:

$$
\text { nse }=\frac{\sum \text { excursion }_{\mathrm{i}}}{\text { total number of tests }}
$$

where nse is the normalized sum of the excursions from the guidelines. The $F_{3}$ factor is then calculated by a formula that scales the nse to yield a range between 0 and 100 .

$$
\mathrm{F}_{3}=\frac{\text { nse }}{(0.01 \text { nse }+0.01)}
$$

The WQI measures the frequency and extent to which selected parameters exceed water quality guidelines at individual monitoring sites. Water quality guidelines are numerical values for physical, chemical, radiological, or biological characteristics of water that indicate that adverse effects may be occurring when exceeded. The water quality guidelines used in the calculations are those defined for the protection of aquatic life. They include national guidelines developed by the CCME, as well as provincial and site-specific guidelines developed by federal, provincial, and territorial partners. If a guideline value is exceeded at a given site, there is an increased probability of an adverse effect on aquatic life at that site $[7,8]$.

Therefore, five categories have been suggested to categorize the water qualities which are summarized in Table 1.

Oregon Water Quality Index (OWQI) creates a score to evaluate the general water quality of Oregon's stream and the application of this method to other geographic regions, which combines eight water quality variables into a single number. The parameters covered in this method are temperature, dissolved oxygen (DO), biochemical oxygen demand (BOD), $\mathrm{pH}$, ammonia and nitrate nitrogen, total phosphorus, total solids and fecal coliform $[15,16]$. The original OWQI was designed after the NSFWQI where the Delphi method was used for variable selection. It expresses water quality status and trends for the legislatively mandated water quality status assessment. The index is free from the arbitration in weighting the parameters and employs the concept of harmonic averaging. The index is free from the arbitration in weighting the parameters and employs the concept of harmonic averaging. The mathematical expression of this WQI method is given by

$$
W Q I=\sqrt{\frac{n}{\sum_{i=1}^{n} \frac{1}{S I_{i}^{2}}}}
$$

Where $n=$ number of subindices; $S /=$ subindex of ith parameter.

The rating of water quality according to this WQI is given in Table 1 .

Weighted Arithmetic Water Quality Index Method classifies the water quality according to the degree of purity by using the most commonly measured water quality variables[9]. The method has been used by various scientists [17-20]. The calculation of WQI was made by using the following equation:

$$
W Q \mathrm{I}=\sum Q_{i} W i / \sum W i
$$

The quality rating scale (Qi) for each parameter is calculated by using this expression:

$$
Q i=100\left[\left(V_{i}-V_{0} / S_{i}-V_{0}\right)\right]
$$

$V i$ is estimated concentration of ith parameter in the analysed water

$V_{0}$ is the ideal value of this parameter in pure water

$V_{0}=0$ (except $\mathrm{pH}=7.0$ and Disolved Oxygen $\left.=14.6 \mathrm{mg} / \mathrm{l}\right)$

$S_{i}$ is recommended standard value of ith parameter .

The unit weight (Wi) for each water quality parameter is calculated by using the following formula: 


\section{$\mathrm{Wi}=\mathrm{K} / \mathrm{Si}$}

Where $\mathrm{K}=$ proportionality constant and can also be calculated by using the following equation:

$$
\mathrm{K}=\frac{1}{\sum\left(\frac{1}{S i}\right)}
$$

The rating of water quality according to this WQI is given in Table 1 .

Tabel 1. Water Rating as per different Water Quality Index methods

\begin{tabular}{|c|c|c|c|c|c|c|c|}
\hline \multicolumn{2}{|c|}{$\begin{array}{l}\text { National Sanitation } \\
\text { Foundation Water } \\
\text { Quality Index } \\
\text { (NSFWQI) }\end{array}$} & \multicolumn{2}{|c|}{$\begin{array}{l}\text { Canadian Council of } \\
\text { Ministers of the } \\
\text { Environment Water } \\
\text { Quality Index } \\
\text { (CCME WQI) }\end{array}$} & \multicolumn{2}{|c|}{$\begin{array}{l}\text { Oregon Water } \\
\text { Quality Index } \\
\text { (OWQI) }\end{array}$} & \multicolumn{2}{|c|}{$\begin{array}{l}\text { Weight Arithmetic } \\
\text { Water Quality Index } \\
\text { (WAWQI) }\end{array}$} \\
\hline $\begin{array}{l}\text { WQI } \\
\text { Value }\end{array}$ & $\begin{array}{l}\text { Rating of } \\
\text { Water } \\
\text { Quality }\end{array}$ & $\begin{array}{c}\text { WQI } \\
\text { Value }\end{array}$ & $\begin{array}{l}\text { Rating of } \\
\text { Water } \\
\text { Quality }\end{array}$ & $\begin{array}{l}\text { WQI } \\
\text { Value }\end{array}$ & $\begin{array}{l}\text { Rating of } \\
\text { Water } \\
\text { Quality }\end{array}$ & $\begin{array}{l}\text { WQI } \\
\text { Value }\end{array}$ & $\begin{array}{l}\text { Rating of } \\
\text { Water } \\
\text { Quality }\end{array}$ \\
\hline $91-100$ & $\begin{array}{c}\text { Excellent } \\
\text { water } \\
\text { quality }\end{array}$ & $95-100$ & $\begin{array}{l}\text { Excellent } \\
\text { water } \\
\text { quality }\end{array}$ & $90-100$ & $\begin{array}{l}\text { Excellent } \\
\text { water } \\
\text { quality }\end{array}$ & $0-25$ & $\begin{array}{c}\text { Excellent } \\
\text { water } \\
\text { quality }\end{array}$ \\
\hline $71-90$ & $\begin{array}{l}\text { Good } \\
\text { water } \\
\text { quality }\end{array}$ & $80-94$ & $\begin{array}{l}\text { Good } \\
\text { water } \\
\text { quality }\end{array}$ & $85-89$ & $\begin{array}{l}\text { Good } \\
\text { water } \\
\text { quality }\end{array}$ & $26-50$ & $\begin{array}{c}\text { Good water } \\
\text { quality }\end{array}$ \\
\hline $51-70$ & $\begin{array}{l}\text { Medium } \\
\text { water } \\
\text { quality }\end{array}$ & $60-79$ & $\begin{array}{c}\text { Fair water } \\
\text { quality }\end{array}$ & $80-84$ & $\begin{array}{c}\text { Fair water } \\
\text { quality }\end{array}$ & $51-75$ & $\begin{array}{c}\text { Poor water } \\
\text { quality }\end{array}$ \\
\hline $26-50$ & $\begin{array}{l}\text { Bad water } \\
\text { quality }\end{array}$ & $45-59$ & $\begin{array}{l}\text { Marginal } \\
\text { water } \\
\text { quality }\end{array}$ & $60-79$ & $\begin{array}{l}\text { Poor } \\
\text { water } \\
\text { quality }\end{array}$ & $\begin{array}{l}76- \\
100\end{array}$ & $\begin{array}{l}\text { Very Poor } \\
\text { water } \\
\text { quality }\end{array}$ \\
\hline $0-25$ & $\begin{array}{c}\text { Very bad } \\
\text { water } \\
\text { quality }\end{array}$ & $0-44$ & $\begin{array}{l}\text { Poor } \\
\text { water } \\
\text { quality }\end{array}$ & $0-59$ & $\begin{array}{l}\text { Very poor } \\
\text { water } \\
\text { quality }\end{array}$ & $\begin{array}{c}\text { Above } \\
100\end{array}$ & $\begin{array}{l}\text { Unsuitable } \\
\text { for drinking } \\
\text { purpose }\end{array}$ \\
\hline
\end{tabular}

\section{Merits and Demerits of Selected Water Quality Index Methods.}

A comparison of all these water quality indices is also performed under the study considering their merits and demerits. Table 3 explains about the merits and demerits of WQI methods.

\section{Table 3. Merits and Demerits of Selected Water Quality Indices}

\begin{tabular}{|c|c|c|}
\hline \multicolumn{3}{|l|}{ National Sanitation Foundation (NSF) WQI } \\
\hline Merits & Demerits & References \\
\hline $\begin{array}{l}\text { 1. Summarizes data in a single index value } \\
\text { in an objective, rapid and reproducible } \\
\text { manner. } \\
\text { 2. Evaluation between areas and identifying } \\
\text { changes in water quality. } \\
\text { 3. Index value relate to a potential water } \\
\text { use. } \\
\text { 4. Facilitates communication with lay } \\
\text { person. }\end{array}$ & $\begin{array}{l}\text { 1. Represents general water quality, it } \\
\text { does not represent specific use of the } \\
\text { water. } \\
\text { 2. Loss of data during data handling. } \\
\text { 3. Lack of dealing with uncertainty and } \\
\text { subjectivity present in complex } \\
\text { environmental issues. }\end{array}$ & {$[21,22]$} \\
\hline \multicolumn{3}{|c|}{ Canadian Council of Ministers of the Environment (CCME) WQI } \\
\hline $\begin{array}{l}\text { 1. Flexibility in the selection of input } \\
\text { parameters and objectives } \\
\text { 2. Adaptability to different legal } \\
\text { requirements and different water uses } \\
\text { 3. Statistical simplification of complex } \\
\text { multivariate data }\end{array}$ & $\begin{array}{l}\text { 1. Missing guidelines about the variables to } \\
\text { be used for the index calculation } \\
\text { 2. Missing guidelines about the objectives } \\
\text { specific to each location and particular } \\
\text { water use } \\
\text { 3. Easy to manipulate (biased) }\end{array}$ & [23] \\
\hline
\end{tabular}




\begin{tabular}{|c|c|c|}
\hline $\begin{array}{l}\text { 4. Clear and intelligible diagnostic for } \\
\text { managers and the general public } \\
\text { 5. Suitable tool for water-quality evaluation } \\
\text { in a specific location } \\
\text { 6. Easy to calculate } \\
\text { 7. Tolerance to missing data } \\
\text { 8. Suitable for analysis of data coming from } \\
\text { automated sampling } \\
\text { 9. Experience in implementation } \\
\text { 10. Considers amplitude (of difference from } \\
\text { the objective) }\end{array}$ & $\begin{array}{l}\text { 4. The same importance is given to all } \\
\text { variables } \\
5 \text {. No combination with other indicators or } \\
\text { biological data } \\
\text { 6. Only partial diagnostic of the water } \\
\text { quality } \\
7 \text {. F1 not working appropriately when too } \\
\text { few variables are considered or when too } \\
\text { much covariance exists among them. The } \\
\text { factor has too much weight in calculating } \\
\text { the index }\end{array}$ & \\
\hline \multicolumn{3}{|l|}{ Oregon WQI } \\
\hline $\begin{array}{l}\text { 1. Un-weighted harmonic square mean } \\
\text { formula used to combine sub-indices allows } \\
\text { the most impacted parameter to impart the } \\
\text { greatest influence on the water quality } \\
\text { index. } \\
\text { 2. Method acknowledges that different } \\
\text { water quality parameters will pose differing } \\
\text { significance to overall water quality at } \\
\text { different times and locations. } \\
\text { 3. Formula is sensitive to changing } \\
\text { conditions and to significant impacts on } \\
\text { water quality. }\end{array}$ & $\begin{array}{l}\text { 1. Does not consider changes in toxics } \\
\text { concentrations, habitat or biology. } \\
\text { 2. To make inferences of water quality } \\
\text { conditions outside of the actual ambient } \\
\text { network site locations is not possible. } \\
\text { 3. Cannot determine the water quality for } \\
\text { specific uses nor can it be used to provide } \\
\text { definitive information about water quality } \\
\text { without considering all appropriate } \\
\text { physical, chemical and biological data. } \\
\text { 4. Cannot evaluate all health hazards } \\
\text { (toxics, bacteria, metals, etc.). }\end{array}$ & {$[1,24]$} \\
\hline \multicolumn{3}{|l|}{ Weight Arithmetic WQI } \\
\hline $\begin{array}{l}\text { 1. Incorporate data from multiple water } \\
\text { quality parameters into a mathematical } \\
\text { equation that rates the health of water body } \\
\text { with number. } \\
\text { 2. Less number of parameters required in } \\
\text { comparison to all water quality parameters } \\
\text { for particular use. } \\
\text { 3. Useful for communication of overall water } \\
\text { quality information to the concerned citizens } \\
\text { and policy makers. } \\
4 \text {. Reflects the composite influence of } \\
\text { different parameters i.e. important for the } \\
\text { assessment and management of water } \\
\text { quality. } \\
\text { 5. Describes the suitability of both surface } \\
\text { and groundwater sources for human } \\
\text { consumption. }\end{array}$ & $\begin{array}{l}\text { 1. WQI may not carry enough information } \\
\text { about the real quality situation of the water. } \\
\text { 2. Many uses of water quality data cannot } \\
\text { be met with an index. } \\
\text { 3. The eclipsing or over-emphasizing of a } \\
\text { single bad parameter value } \\
\text { 4. A single number cannot tell the whole } \\
\text { story of water quality; there are many other } \\
\text { water quality parameters that are not } \\
\text { included in the index. } \\
5 \text {. WQI based on some very important } \\
\text { parameters can provide a simple indicator } \\
\text { of water quality. }\end{array}$ & {$[25,26]$} \\
\hline
\end{tabular}

\section{Conclusions}

The water quality varies according to the type of use. The water quality index is realised to provide a number for comparing the water quality of different sources and in monitoring the changes in the water quality of a given source as a function of time and other influencing factors. The water quality expressed in indices is a very helpful tool to represent water quality in a simple and understandable manner.

Water quality indices have proved to be a useful tool for summarizing and transmitting information generated by individual parameters (physical, chemical and biological parameters) and their concentrations present in a sample to managers and the general public.

Despite the efforts of researchers around the world, there is not so far a water quality index that can be universally applied by water agencies, users and administrators from different countries. 
The water quality indices presented in this paper will be used for characterization of surface waters in Roumania ( Danube, Jiu) used as source of drinking water.

\section{Acknowledgement}

The research was financed by the Romanian „Program Nucleu”, PN 16-25 0201.

\section{References}

[1] Cude, C. G. (2001). Oregon water quality index: A tool for evaluating water quality management effectiveness. Journal of the American Water Research Association, 37, 125-137.

[2] Liou, S. M., Lo, S. L., \& Wang, S. H. (2004). A generalized water quality index for Taiwan. Environmental Monitoring and Assessment, 96, 35-32.

[3] Pesce, S. F., \& Wunderlin, D. A. (2000). Use of water quality indices to verify the impact of Cordoba City (Argentina) on Suquia River. Water Research, 34, 2915-2926.

[4] ISC (2005). Index of stream condition: The second benchmark of Victorian River. Victorian Government Department of Sustainability and Environment, Melbourne, August 2005. Retrieved on March 29, 2007 from www.vicwaterdata.net.

[5] Khan, F., Husain, T., \& Lumb, A. (2003). Water quality evaluation and trend analysis in selected watersheds of the Atlantic region of Canada. Environmental Monitoring and Assessment, 88, 221- 242.

[6] Lumb, A., Halliwell, D., \& Sharma, T. (2006). Application of the CCME water quality index to monitor water quality: A case study of the Mackenzie River Basin, Canada. Environmental Monitoring and Assessment, 113, 411-429.

[7] CCME (2001). Canadian water quality guidelines for the protection of aquatic life: CCME Water QualityIndex 1.0, user's manual. In Canadian environmental quality guidelines, 1999, Canadian Council of Ministers of the Environment, Winnipeg, Manitoba. Retrieved on March 29, 2007, from http: //www.ccme.ca/assets/pdf/wqi_usermanualfctsht_e.pdf.

[8] CCME (2005). Canadian environmental sustainability indicators. Freshwater quality indicator: Data sources and methods. Catalogue no. 16-256-XIE. Retrieved on March 29, 2007, from http://www.statcan.ca/bsolc/english/bsolc?catno=16-256-XIE\#formatdisp.

[9] Smith, D. G. (1989). A new form of water quality index for rivers and streams. Water Science and Technology,21(2), 123-127.

[10]Smith, D. G. (1990). A better water quality index for rivers and streams. Water Research, 10, 12371244.

[11] Horton, R.K., "An index number system for rating water quality", Journal of the Water Pollution Control Federation, 37(3). 300-305. 1965

[12] Brown, R.M., McClelland, N.I., Deininger, R.A. and Tozer, R.G., (1970) "Water quality index-do we dare?", Water Sewage Works, 117(10). 339-343.

[13] Kumar, D. and Alappat, B. (2009), "NSF-Water Quality Index: Does It Represent the Experts' Opinion?", Practice Periodical of Hazardous, Toxic, and Radioactive Waste Management, 13(1). 75-79.

[14] Tyagi,S, Bhavtosh S., Prashant S., Rajendra D. (2013):Water Quality Assessment in Terms of Water Quality Index, American Journal of Water Resources 1(3) 34-38

[15] Dunnette, D.A., (1979). "A geographically variable water quality index used in Oregon", Journal of the Water Pollution Control Federation, 51(1). 53-61.

[16] Dinius, S.H., (1987) "Design of an index of water quality", Water Resources Bulletin, 23(5). 833-843.

[17]Chauhan, A. and Singh, S., (2010) "Evaluation of Ganga water for drinking purpose by water quality index at Rishikesh, Uttarakhand, India", Report Opinion, 2(9). 53-61.

[18] Chowdhury, R.M., Muntasir, S.Y. and Hossain, M.M., (2012) "Water quality index of water bodies along Faridpur-Barisal road in Bangladesh", Global Engineering Technology Review , 2(3). 1-8.

[19] Rao, C.S., Rao, B.S., Hariharan, A.V.L.N.S.H. and Bharathi, N.M. (2010), "Determination of water quality index of some areas in Guntur district Andhra Pradesh", International Journal of Applied Biology and Pharmaceutical Technology I(1). 79-86. 
[20] Balan, I.N., Shivakumar, M. and Kumar, P.D.M. (2012), "An assessment of ground water quality using water quality index in Chennai, Tamil Nadu, India", Chronicles of Young Scientists., 3(2). 146-150.

[21] Mnisi, L.N., (2010) "Assessment of the state of the water quality of the Lusushwana River, Swaziland, using selected water quality indices". M.Sc. Thesis, University of Zimbabwe, Harare.

[22] Wills, M. and Irvine, K.N., (1996). "Application of the national sanitation foundation water quality index in Cazenovia Creek", NY, Pilot watershed management project. Middle States Geographer, 95-104.

[23] Terrado, M., Barcelo, D., Tauler, R., Borrell, E. and Campos, S.D. (2010), "Surface-water-quality indices for the analysis of data generated by automated sampling networks", Trends in Analytical Chemistry., 29(1). 40-52.

[24] Hubler, S., Miller, S., Merrick, L., Leferink, R. and Borisenko, A., (2009) "High level indicators of Oregon's forested streams", Laboratory Environment Assessment Division, Hillsboro, Oregon.

[25] Akoteyon, I.S., Omotayo, A.O., Soladoye, O. and Olaoye, H.O. (2011), "Determination of water quality index and suitability of urban river for municipal water supply in Lagos-Nigeria", European Journal of Scientific Research, 54 (2). 263-271.

[26] Yogendra, K. and Puttaiah E.T. (2008), "Determination of water quality index and suitability of an urban waterbody in Shimoga Town, Karnataka", Proceedings of Taal 2007: The 12th World Lake Conference, pp. 342-346. 